Original Research Article

\title{
Comparative evaluation of cost-effectiveness between typical antipsychotic haloperidol and atypical antipsychotics olanzapine, risperidone and aripiprazole in the treatment of stable schizophrenia
}

\author{
Subhash Vishal, Mirza A. Beg*, Shakti B. Dutta, Sumit Khatri, Shobhit Garg, \\ Nand Kishore Singh, Amanjot Kaur
}

Department of Pharmacology, Shri Guru Ram Rai Institute of Medical and Health Sciences (SGRRIM \& HS), Patel Nagar, Dehradun, Uttarakhand, India

Received: 24 May 2017

Accepted: 24 June 2017

*Correspondence to:

Dr. Mirza A. Beg,

Email: mabeg1997@gmail.com

Copyright: () the author(s), publisher and licensee Medip Academy. This is an openaccess article distributed under the terms of the Creative Commons Attribution NonCommercial License, which permits unrestricted noncommercial use, distribution, and reproduction in any medium, provided the original work is properly cited.

\begin{abstract}
Background: Schizophrenia patients mostly require life-long treatment. For such long-term treatments, cost is an important factor. Estimate of cost in terms of efficacy can give idea to prescribers about the relative financial burden posed by various typical and newer antipsychotics in schizophrenic patients.

Methods: A total of 98 stable schizophrenic patients were enrolled in this open label study over a period of 1 year. Patients were divided in four groups, group-I received Haloperidol $(n=24)$, group-II received Olanzapine $(n=25)$, group-III received Risperidone $(n=25)$ and group-IV received Aripiprazole $(n=24)$. The patients were given drugs on the basis of physician's discretion, depending upon the condition of the patient at the time of presentation. Patients were followed up to 16 weeks. Direct treatment costs and efficacy of treatment in terms of Clinical Global Impression - Efficacy Index CGI (EI) noted and average costeffectiveness worked out.

Results: In this open label study, the mean age of patients was $35.05 \pm 1.30$. The average cost-effectiveness ratio was 26.25 for haloperidol, 10.12 for Olanzapine, 9.83 for Risperidone and 25.92 for Aripiprazole.

Conclusions: Risperidone was found to be most cost-effective, followed by olanzapine, then by aripiprazole, whereas haloperidol was found least cost effective.
\end{abstract}

Keywords: Atypical, Antipsychotics, Aripiprazole, Cost-effectiveness, Haloperidol, Olanzapine, Risperidone, Typical/atypical antipsychotics

\section{INTRODUCTION}

Schizophrenia is a chronic, debilitating and an enigmatic major psychiatric disorder requiring life-long treatment. ${ }^{1}$ Schizophrenia is present in $0.85 \%$ of individuals worldwide, with a lifetime prevalence of $\sim 1-1.5 \% .^{2}$

The financial costs of treating schizophrenia are quite high. This is due to various factors like early onset of the disease, fluctuations in mental stability despite treatment, need of hospital care, rehabilitation and support services. So the socio-economic status of the society in terms of loss of productivity and mortality imparts a significant problem in the course of the disease. ${ }^{3}$

Evolution of new antipsychotic era lead to the introduction of new, novel class of antipsychotic agents called as atypical antipsychotics. They have fewer neurological adverse effects and efficacy against a broader range of psychotic symptoms. $^{4}$

Not only do the newer agents cause fewer extrapyramidal side effects, but also they may have greater effects against negative symptoms of schizophrenia, cognitive defects and depression that may co-exist with psychosis. ${ }^{5}$ 
Keeping this in mind, the present study was designed with the aims and objectives to compare the cost-effectiveness of conventional antipsychotic (haloperidol) with newer antipsychotics (Olanzapine, risperidone and aripiprazole) in stable schizophrenic patients attending psychiatry OPD of SGRRIM \& HS, Dehradun, Uttarakhand, India.

\section{METHODS}

This study was carried out in the Department of Pharmacology and Psychiatry, Shri Guru Ram Rai Institute of Medical and Health Sciences, Patel Nagar, Dehradun for a period of 1 year from $1^{\text {st }}$ January 2015 to $31^{\text {st }}$ December 2015. A written informed consent was taken from each and every legal guardian of schizophrenic patient after full explanation of elements. A total of ninetyeight stable schizophrenic patients attending Psychiatry OPD were included in the study.

\section{Study design}

This study was comparative evaluation of costeffectiveness between conventional antipsychotic (Haloperidol) and newer antipsychotics (Olanzapine, Risperidone and Aripiprazole) among stable schizophrenic patients.

Patient Selection was based on ICD-10 and BPRS Scores.

\section{Inclusion criteria}

Stable schizophrenic patients of Both sexes with age ranging from 18 to 70 years, and initial BPRS score of $\geq 24$ with Clinical Global Impression Severity Rating Scale more than or equal to 4. Patients excluded were having age less than 18 years or more than 70 years, pregnant or lactating women, patients with acute emergencies or with impaired renal or hepatic function, patients having history of hypersensitivity / allergy to any of the drugs included in study, or with history of any systemic illness.

Patients were divided into four study groups, group-I received Haloperidol $(n=24)$, group-II received Olanzapine $(n=25)$, group-III received Risperidone $(n=25)$ and group-IV received Aripiprazole $(n=24)$. The patients were given drugs on the basis of physician's discretion, depending upon the condition of the patient at the time of presentation.

Cost-effectiveness: For efficacy, Clinical Global Impression - Efficacy Index CGI (EI) was used. For costs, direct medication costs (in Indian rupees) were analysed, compared, estimated and discussed between each treatment group receiving Haloperidol, Olanzapine, Risperidone and Aripiprazole.

\section{RESULTS}

Cost-effectiveness of antipsychotic medicines included in study were assessed by direct medication costs and
CGI(EI) scale at the beginning of the study ( 0 week) and subsequently at the end of 2, 4, 6, 12 and 16 weeks.

\section{Demographic profile}

A total of 98 patients with age ranging from 18 to 70 were included in the study. Out of these 98 patients, $59(60.20 \%)$ were male and $39(39.80 \%)$ were female. 72 patients $(73.47 \%)$ were in age-range of 18 to 40 years, 17 patients $(17.35 \%)$ were in age-range of 41 to 55 years and 9 patients $(9.18 \%)$ were in age-range of 56 to 70 years (Table $1)$. Mean age of patients in our study was $35.05 \pm 1.30$ years.

Table 1: Age-wise distribution of study patients.

\begin{tabular}{|llll|}
\hline \multirow{2}{*}{ gge group } & \multicolumn{2}{l}{ Gender } & \multicolumn{2}{l|}{ Total } \\
\cline { 2 - 4 } & Male & Female & \\
\hline $18-40$ & 44 & 28 & $72(73.47 \%)$ \\
\hline $41-55$ & 10 & 7 & $17(17.35 \%)$ \\
\hline $56-70$ & 5 & 4 & $9(9.18 \%)$ \\
\hline
\end{tabular}

Cost-Effectiveness of Antipsychotic Medications: The Average Cost-Effectiveness Ratio is calculated by using mean daily costs and Clinical Global Improvement Efficacy Index (CGI-EI) scores.

Table 2: Mean age in different study groups.

\begin{tabular}{|llll|}
\hline Drug group & Gender & Age \\
\hline $\begin{array}{l}\text { Haloperidol } \\
(\mathrm{n}=24)\end{array}$ & 14 & 10 & $39.75 \pm 3.57$ \\
\hline $\begin{array}{l}\text { Olanzapine } \\
(\mathrm{n}=25)\end{array}$ & 16 & 9 & $36.68 \pm 2.28$ \\
\hline $\begin{array}{l}\text { Risperidone } \\
(\mathrm{n}=25)\end{array}$ & 15 & 10 & $34.36 \pm 1.93$ \\
\hline $\begin{array}{l}\text { Aripiprazole } \\
(\mathrm{n}=24)\end{array}$ & 14 & 10 & $29.38 \pm 1.77$ \\
\hline Total & 59 & 39 & $35.05 \pm 1.30$ \\
\hline
\end{tabular}

Mean Daily Costs: Direct medication costs (MRP in Rs.) of brands of study drugs most commonly prescribed were noted from hospital pharmacy. Overall mean daily dose over the study period (i.e. for 16 weeks of study) for all four drugs were used to calculate final mean daily costs.

Table 3: Mean daily dose of antipsychotics.

\begin{tabular}{|ll|}
\hline Drugs & Men Daily dose (in mg/day) \\
\hline Haloperidol & 9.23 \\
\hline Olanzapine & 8.58 \\
\hline Risperidone & 2.81 \\
\hline Aripiprazole & 12.77 \\
\hline
\end{tabular}

Mean daily doses of antipsychotics over the study period i.e. 16 weeks' duration were: $9.23 \mathrm{mgs}$ of Haloperidol, 
$8.58 \mathrm{mgs}$ of Olanzapine, $2.81 \mathrm{mgs}$ of Risperidone and $12.77 \mathrm{mgs}$ of Aripiprazole (Table 3).

All doses of antipsychotics were well within normal therapeutic range. Cost of total treatment with each antipsychotic medicine over the study period i.e. 16 weeks was find out (Table 4).

\section{Effectiveness}

Clinical Global Impression CGI (EI) subscale was used to measure the effectiveness of antipsychotic medicine (Table 5).

Average Cost-effectiveness Ratio $=$ Mean daily $\operatorname{cost} \mathrm{X}$ CGI-EI.

Table 4: Cost of antipsychotics prescribed over the study period.

\begin{tabular}{|lllllll|}
\hline DRUG & $\begin{array}{l}\text { Strength } \\
\text { (in } \mathbf{m g})\end{array}$ & $\begin{array}{l}\text { MRP per strip of } \\
\mathbf{1 0} \text { tablets (Rs) }\end{array}$ & $\begin{array}{l}\text { Cost per } \\
\text { mg (Rs) }\end{array}$ & $\begin{array}{l}\text { Mean Daily } \\
\text { Dose (in } \mathbf{~ m g})\end{array}$ & $\begin{array}{l}\text { Mean Daily } \\
\text { cost (Rs) }\end{array}$ & $\begin{array}{l}\text { Total Treatment } \\
\text { cost (Rs) }\end{array}$ \\
\hline Haloperidol & 5 & 43.35 & 0.87 & 9.23 & 8.03 & 899.36 \\
\hline Olanzapine & 10 & 59.00 & 0.59 & 8.58 & 5.06 & 566.72 \\
\hline Risperidone & 2 & 28.00 & 1.40 & 2.81 & 3.93 & 440.16 \\
\hline Aripiprazole & 10 & 72.00 & 0.72 & 12.77 & 9.19 & 1029.28 \\
\hline
\end{tabular}

Total study duration $=16$ weeks $=112$ days

Table 5: CGI subscale analysis (EI) scores at $0,2,4,6,12$ and 16 weeks.

\begin{tabular}{|c|c|c|c|c|}
\hline \multicolumn{5}{|c|}{ CGI (EI) Subscale analysis } \\
\hline $\begin{array}{l}\text { Time interval } \\
\text { (in weeks) }\end{array}$ & $\begin{array}{l}\text { Haloperidol } \\
(\mathrm{n}=24)\end{array}$ & $\begin{array}{l}\text { Olanzapine } \\
(\mathbf{n}=25)\end{array}$ & $\begin{array}{l}\text { Risperidone } \\
(n=25)\end{array}$ & $\begin{array}{l}\text { Aripiprazole } \\
(n=24)\end{array}$ \\
\hline 0 - 2 weeks & $2.29 \pm 0.20$ & $1.04 \pm 0.04$ & $1.80 \pm 0.32$ & $1.08 \pm 0.08$ \\
\hline 2 - 4 weeks & $2.79 \pm 0.40$ & $1.96 \pm 0.31$ & $2.16 \pm 0.44$ & $2.13 \pm 0.36$ \\
\hline $4-6$ weeks & $2.38 \pm 0.46$ & $2.52 \pm 0.43$ & $2.68 \pm 0.39$ & $3.46 \pm 0.42$ \\
\hline $6-12$ weeks & $3.04 \pm 0.42$ & $2.28 \pm 0.41$ & $3.04 \pm 0.41$ & $3.88 \pm 0.47$ \\
\hline 12 - 16 weeks & $4.50 \pm 0.27$ & $2.20 \pm 0.42$ & $2.84 \pm 0.46$ & $3.54 \pm 0.43$ \\
\hline Mean & $3.00 \pm 0.16$ & $2.00 \pm 0.17$ & $2.50 \pm 0.24$ & $2.82 \pm 0.18$ \\
\hline
\end{tabular}

(Mean \pm S.E.)

Note: CGI-EI score of 1 shows maximum efficacy score and 16 shows unchanged/worse therapeutic effect. Thus following formula was used to calculate cost-effectiveness of antipsychotic medicines:

Thus, risperidone was found to be most cost-effective drug in study, followed by olanzapine and aripiprazole, and haloperidol being least cost-effective (Table 6).

Table 6: Cost-effectiveness of antipsychotic drugs prescribed in study.

\begin{tabular}{|llll|}
\hline $\begin{array}{l}\text { Antipsychotic } \\
\text { Drug }\end{array}$ & $\begin{array}{l}\text { Mean } \\
\text { daily } \\
\text { cost (Rs.) }\end{array}$ & $\begin{array}{l}\text { Mean } \\
\text { CGI - } \\
\text { EI score }\end{array}$ & $\begin{array}{l}\text { Average cost } \\
\text { effectiveness } \\
\text { ratio }\end{array}$ \\
\hline Haloperidol & 8.75 & 3.00 & 26.25 \\
\hline Olanzapine & 5.06 & 2.00 & 10.12 \\
\hline Risperidone & 3.93 & 2.5 & 9.83 \\
\hline Aripiprazole & 9.19 & 2.82 & 25.92 \\
\hline
\end{tabular}

\section{DISCUSSION}

Schizophrenia is characterized by various ominous symptoms and behavioural dysfunction, often requiring life-long treatment. Both conventional as well as newer antipsychotics have their own advantages and disadvantages. Any drug may appear cheaper but its relatively low efficacy or adverse safety profile may reflect in added treatment costs. The purpose of our study was to compare typical antipsychotic Haloperidol against atypical antipsychotics olanzapine, risperidone and aripiprazole against both parameters i.e. cost and efficacy in terms of cost-effectiveness of antipsychotic medications to find out the imposed financial burden on patient.

The socio-demographic profile of schizophrenic patients in our study showed that maximum number of patients (72\%) was from age group 18-40 years of age. Previous study in India also showed that maximum number of patients $(75.4 \%)$ was from age-group 21-40 years. ${ }^{6}$

Mean age of patients in our study was $35.05 \pm 1.30$ years, that is quite similar to mean age reported in earlier Indian studies i.e. 38.2 years, $31 \pm 9.3$ years and slightly higher than one study (showing target young population) of $29.5 \pm 7.7$ years. $^{7-9}$

Gender ratio in our study (Male:Female) was 1.51:1 (60.20:39.80), which is in accordance with earlier studies $\left(\mathrm{M}: \mathrm{F}=63: 37,57: 43,55: 45\right.$ respectively) ${ }^{7,9}$ But in contrast with another Indian study. ${ }^{8}$ 
In the CGI efficacy index, olanzapine showed maximum efficacy, followed by risperidone and aripiprazole, newer antipsychotics are being superior to conventional antipsychotic i.e. haloperidol. These findings are in collaboration with earlier report of a meta-analysis of various comparative studies of conventional and newer antipsychotics suggesting that the newer agents were equivalent to or may exceed the efficacy of the conventional antipsychotics. ${ }^{1}$

Evaluation of cost-effectiveness of antipsychotic drugs is an important issue while treating a chronic disorder like schizophrenia. Final daily costs (in Rs.) of haloperidol, the conventional antipsychotic is much higher as compared to newer antipsychotic olanzapine, risperidone and aripiprazole respectively. Also, the mean CGI-Efficacy Index scores was highest with haloperidol. As a result, the cost-effectiveness of study drugs was: Risperidone being most cost-effective followed by Olanzapine, then by Aripiprazole and Haloperidol being least cost-effective. The reason of Risperidone being most cost-effective was its low daily required dose and hence low costs of treatment that finally reflected in comparatively low treatment costs. One study observed that olanzapine treated patients experienced clinical improvement that translated into savings in cost of care. ${ }^{10}$ Another study had shown olanzapine to be a cost-effective alternative to conventional agent for the treatment of moderate to severely ill patients with long-standing schizophrenia. ${ }^{11}$

\section{Limitations}

This study was an open-label study. Both the doctor as well as patients was aware of the prescribed drugs. Hence, expected more chances of errors. Also, the sample size was small. Only 98 patients were included in the study, which may not be sufficient enough to demonstrate intergroup differences in efficacy of study drugs. Furthermore, the duration of the follow-up was limited to 16 weeks. A longer follow-up period may have yielded more reliable and meaningful results. Hence in the view of these limitations, further studies are required with larger sample size and longer duration to evaluate the cost-effectiveness of various typical and atypical antipsychotic medications.

\section{CONCLUSION}

From the results of the present comparative clinical study of conventional and newer antipsychotics, it was found that overall, the use of newer antipsychotics like Risperidone and Olanzapine should reduce the treatment costs of schizophrenia and impose lesser financial burden to the patients' families.

Funding: No funding sources Conflict of interest: None declared

Ethical approval: The study was approved by the Institutional Ethics Committee

\section{REFERENCES}

1. Freedman R. Drug Therapy Schizophrenia. N Engl J Med. 2003;349(18):1738-49.

2. Reus VI. Mental Disorders. In: Kasper, Fauci, Hauser, Longo, Jameson, Loscalzo et al Harrison's principles of internal medicine $19^{\text {th }} \mathrm{Ed}$. McGraw-Hill Education. U.S.A.; 2015:2708-2721.

3. Sadock BJ, Sadock VA. Schizophrenia. In: Text Book of Kaplan \& Sadock's Synopsis of Psychiatry Behavioral Sciences / Clinical Psychiatry. 10 ${ }^{\text {th }}$ Ed. Lippincott Williams and Wilkins. Philadelphia. U.S.A.; 2013:470.

4. Sadock BJ, Sadock VA. Dopamine Receptor Antagonists. In: Text Book of Kaplan and Sadock's Synopsis of Psychiatry Behavioral Sciences / Clinical Psychiatry $9^{\text {th }}$ Ed. Lippincott Williams and Wilkins. Philadelphia. U.S.A.; 2003:1050.

5. Sadock BJ, Sadock VA. Dopamine Receptor Antagonists. Typical Antipsychotics. In: Kaplan and Sadock's Synopsis of Psychiatry Behavioral Sciences / Clinical Psychiatry $10^{\text {th }}$ Ed. Lippincott Williams and Wilkins. Philadelphia. U.S.A.; 2013:1043-1044.

6. Aruna D, Sudhakar TP. A retrospective study of the functional outcome of schizophrenia depending on premorbid personality at the time of diagnosis. J Clin Sci Res. 2014;3:166-73.

7. Koujalgi SR, Patil SR. Comparison of demographic profile of patient with schizophrenia and depression. Journal of the Scientific Society. 2013;40(1):20-4.

8. Mandal P, Prakash S, Sagar R. Primary caregivers of schizophrenia outpatients: burden and its correlates. Delhi Psychiatry Journal. 2014;17(2):343-8.

9. Saravanan B, Jakob KS, Johnson S, Prince M, Bhugra D, David AS. Outcome of first-episode schizophrenia in India: longitudinal study of effect of insight and psychopathology. The British Journal of Psychiatry. 2010;196:454-9.

10. Edgell ET, Andersen SW, Johnstone BM, Dulisse B, Revicki D, Breier A. Olanzapine versus risperidone. A prospective comparison of clinical and economic outcomes in schizophrenia. Pharmacoeconomics. 2000 Dec;18(6):567-79.

11. Foster RH. A pharmacoeconomic review of its use in schizophrenia. Pharmacoeconomics. 1999;15:611-40.

Cite this article as: Subhash V, Beg MA, Dutta SB, Khatri S, Garg S, Singh NK, et al. Comparative evaluation of cost-effectiveness between typical antipsychotic haloperidol and atypical antipsychotics olanzapine, risperidone and aripiprazole in the treatment of stable schizophrenia. Int J Basic Clin Pharmacol 2017;6:1965-8. 